

\section{Empirical Look at the Factors Affecting Perception of Business Ethics in Turkey}

\author{
Vedat Akman Ph.D
}

\section{Introduction}

Factors influencing business ethics have attracted attention in Turkey following a series of collapses in the Turkish financial system. In today's business scandals fundamentals are not lack of intelligence or education anymore but instead a lack of business ethics. (Choe Kum - Lung, 2010) This current situation has intensified the importance of business ethics in the governance of corporations especially in developing countries. (Barclay and Smith, 2003) In the case of Turkey, there are about 15 professional associations giving information or education which are in general accepted as public bodies having either codes of conduct on its website, have ethics commission or professional ethics rules listed on their websites. (TYEC report III, 2009) A code of ethics is a crucial element in forming a professional. The distribution of the PA's according to three choice of criterias by the TYEC are (TYEC Report-II, 2009); Turkish Dental Association, Turkish Pharmacist Association, The Confederation of Turkish Tradesman and Craftsmen, Union of Chambers of Turkish Engineers and Architects, Turkish Medical Associations, Turkish Veterinary Medical Association, Union of Turkish Bar Associations, Union of Turkish Public notaries, The Union of Certified Public Accountants and Sworn-in Certified Public Accountants of Turkey, Association of the Insurance and Reisurance Companies in Turkey, The Union of Chambers and Commodities Exchanges of Turkey, Union of Turkish Chambers of Agriculture, The Association of Capital Market Intermediary Institution of Turkey, The Banks Association of Turkey and The Central Union of Agricultural Credit Cooperatives of Turkey. Though it is a Constitutional obligation, only the Confederation of Turkish Tradesmen and Craftsmen of the 15 PA's has “public servants ethicl rules". (TYEC Report-II, 2009) Union of Turkish Chambers of Agriculture is the only PA that has no codes of conduct, High Pride/Discipline/Ethics Commission and profesional ethical rules. None of the 15 has all 3 criterias complete. (TYEC ReportII, 2009) There are mainly 3 levels of factors affecting the ethical behavior macro-level, (culture, economics, technology, religion, law), middle-level (competition, job, organizational culture, leader), and micro-level or individual level (demographics, family, values, beliefs). (Tahmasebi, 2010; Dibavar, 2010; Pirsemsari, 2010) Factors affecting perceptions of bussiness ethics are individual characteristics (personal values), structural variables (leader behavior), organization culture, environment, and family. According to model of relationship among environment, values and individual ethics (Winesa and Napier, 1992), gender, education, age, education level and choice of profession may be the significant moderators in explaining perception of business ethics.

\section{Background}

Research on the determinants of ethical decision making in the literature include; competition and business ethics (Hegarty and Sims, 1978), peer influence on ethics (Jones and Kavanagh, 1996), quality of the work experience on business ethics (Jones and Kavanagh, 1996), managerial influences on ethics (Jones and Kavanagh, 1996; Stead et al., 1990); reinforcement contingencies (Hegarty and Sims, 1978; Jansen and Von Glinow, 1985; Stead et al, 1990; Trevino, 1986); and ethical decision making models (Dubinsky and Loken, 1989; Ferrell and Gresham, 1985; Ferrell et al., 1989; Hunt and Trevino, 1986). 


\subsection{Literature}

In business ethics literature researches are categorized in two main categories mainly conceptual and empirical. (Preble and Reichel, 1988) Our research approach is empirical which places emphasis on examining prevailing business ethics perceptions and attitudes in Turkey. There is a full body of literature in general supporting difference in attitudes on gender perception of business ethics (Dawson, 1997; Gilligan, 1982; Peterson, Rhoads, and Vaught, 2001) but not on Turkey's case. In contrast to (Cortese 1989; Kidwell, Stevens and Bethke, 1987; Sikula and Costa, 1994). There are also studies supporting existence of positive relation to attitudes with differences in age towards perception of business ethics in general (Harris, 1990; Mason et al, 1996; Singhapakdi et al, 1999; Ruegger et al, 1992; Serwinek, 1992; Hofsted, 1991; Peterson et al, 2001; Kohlberg, 1969; Dowson, 1997 and Peterson et al, 2001) in contrast to (Cortese, 1989) who claims no significant relation exists. There is a lack of literature for Turkey.

There is also body of literature claiming a significant relationship between culture and perception of business ethics in general (Erdener, 1996; Jackson and Artola, 1997; Robertson, Crittendan, Brady and Hoffman, 2002; Singhapak di, Karande, Rao and Vitell, 2001) with very little research on Turkey.

\section{Methodology}

\subsection{Sample}

For this study, five hundred selfadministered questionnaires were collected from adults working in and around Istanbul area. Snowball sampling method was used in which questionnaires were distributed to business ethics students at Kadir Has University, to their working friends, relatives and colleagues. Respondents were also interviewed by students. Participation to our survey was voluntary and no remuneration was offered. Prior to performing the necessary statistical analysis, frequency distributions were tabulated for each item to ascertain possible response biass. In addition, a visiual inpection was also performed to identify possible anomalies in which 230 respondents out of 730 were eliminated leaving us with total of 500 respondents.

All respondents were asked to respond each 21 statements. A five-point response scale was employed ( $1=$ "strongly agree" to $5=$ "strongly disagree") for all items indicating their belief about that particular situation. Our analyses included descriptive statistics, correlations and regression analysis. Correlations were calculated to gain an initial understanding of the relationship between the variables.

\subsection{Instruments}

The survey instrument consists of 21 statements that describe a specific event that has some kind of ethical choice connotation. Survey is conducted in Turkish for clarity, readability and understandability by the Turkish respondents. In addition, respondents were asked to provide demographic data about themselves. The data collected from the survey was analysed by reliability test, frequency analysis, factor analysis and regression analysis ANOVA test.

Two hypothesises will be tested. The hypotheses are listed below:

\section{Hypothesis 1:}

H0: Age and Gender is a positive determinant of attitude towards business ethics.

H1: Age and Gender is not a positive determinant of attitude towards business ethics.

\section{Hypothesis 2:}

H0: Job and Sector is a positive determinant of attitude towards business ethics.

H1: Job and Sector is not a positive determinant of attitude towards business ethics. 
In order to test the hypothesizes, factor analysis was used twice. The first factor analysis was done to the 21 questions in order to gain the factors related to the erthical variables.

The second factor analysis was done to gain the important factors for the demographic issues. The variables for each factor analysis were retained for regression analysis.

The article continuous with the two different factor analysis and then the regression analysis is done to test the two hypothesises.

\section{Analysis and Results}

\subsection{Reliability Test}

When reliability analysis was tested with the 21 questiones included in the questtionnaire the cronbach alpha was found to be 0,692 which means that the data collected is consistently reliable to be analysed.

\subsection{Frequency Analysis}

Demographic data were also summarized to provide insights into the nature of the participants. Demographic characteristics of Turkish respondents are as follows.

When reliability analysis was tested with the 21 questiones included in the questtionnaire the cronbach alpha was found to be 0,692 which means that the data collected is consistently reliable to be analysed.

\begin{tabular}{|rr|r|r|r|r|}
\hline & & Age & \multicolumn{2}{c|}{$\begin{array}{c}\text { Cumulative } \\
\text { Percent }\end{array}$} \\
\hline & Frequency & Percent & Valid Percent & 30,8 \\
& $18-25$ & 154 & 30,8 & 30,8 & 56,4 \\
& $26-30$ & 128 & 25,6 & 25,6 & 71,8 \\
$31-35$ & 77 & 15,4 & 15,4 & 84,4 \\
$36-40$ & 63 & 12,6 & 12,6 & 94,6 \\
$41-50$ & 51 & 10,2 & 10,2 & 100,0 \\
$51-60$ & 27 & 5,4 & 5,4 & \\
\hline
\end{tabular}

Table 1: Age Distribution

\begin{tabular}{|c|c|c|c|c|c|}
\hline \multicolumn{6}{|c|}{ Gender } \\
\hline & & Frequency & Percent & Valid Percent & $\begin{array}{c}\text { Cumulative } \\
\text { Percent }\end{array}$ \\
\hline \multirow[t]{3}{*}{ Valid } & Female & 245 & 49,0 & 49,0 & 49,0 \\
\hline & Male & 255 & 51,0 & 51,0 & 100,0 \\
\hline & Total & 500 & 100,0 & 100,0 & \\
\hline
\end{tabular}

Table 2: Gender Distribution

\begin{tabular}{|c|c|c|c|c|c|}
\hline \multicolumn{6}{|c|}{ Education } \\
\hline & & Frequency & Percent & Valid Percent & $\begin{array}{c}\text { Cumulative } \\
\text { Percent }\end{array}$ \\
\hline \multirow[t]{5}{*}{ Valid } & primary school & 19 & 3,8 & 3,8 & 3,8 \\
\hline & secondary school & 7 & 1,4 & 1,4 & 5,2 \\
\hline & high school & 105 & 21,0 & 21,0 & 26,2 \\
\hline & University & 369 & 73,8 & 73,8 & 100,0 \\
\hline & Total & 500 & 100,0 & 100,0 & \\
\hline
\end{tabular}

Table 3: Education Distribution 
Job

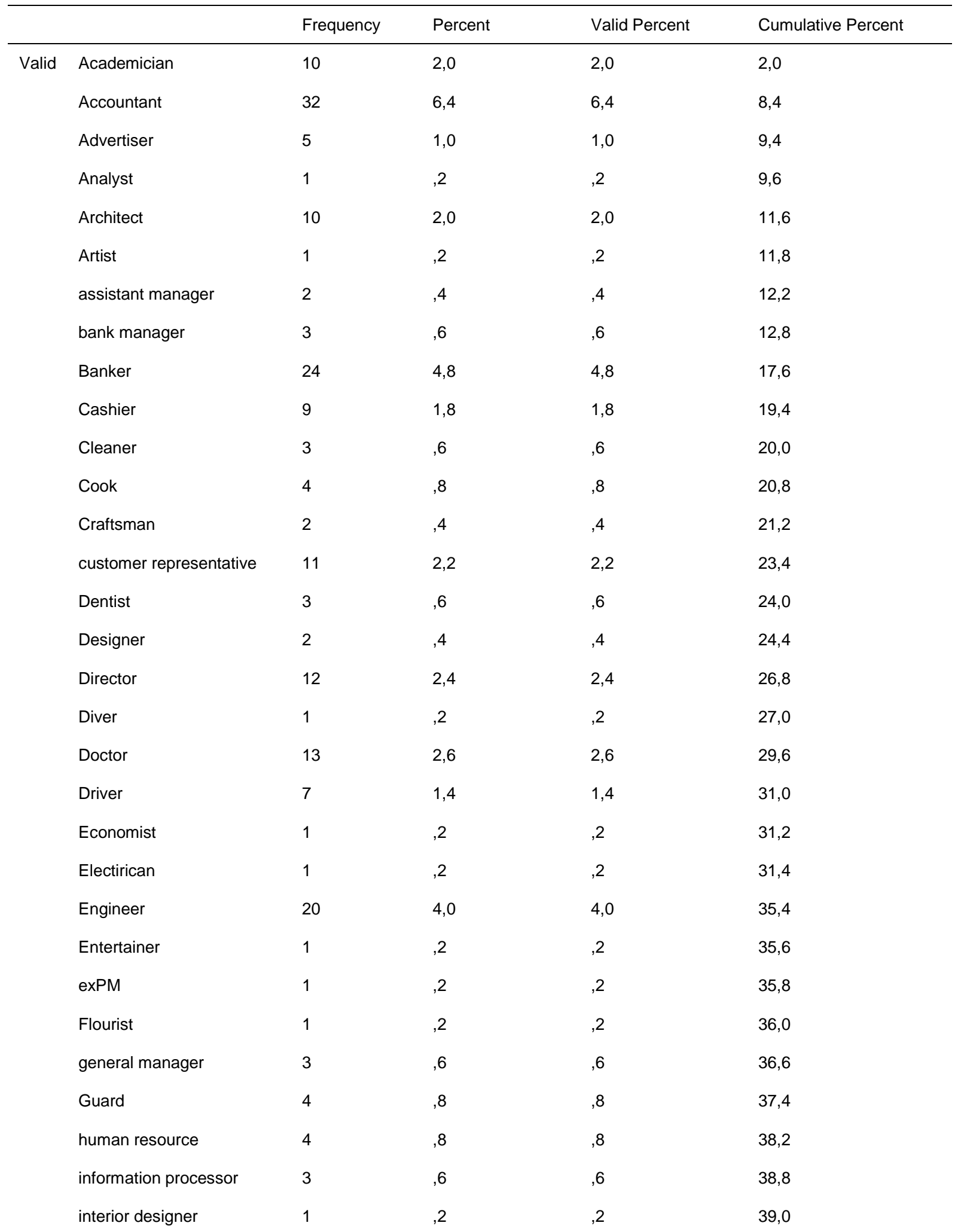

Vedat AKMAN Ph.D

$\mathrm{P}$ a g e |4|Emerging Markets Journal 


\begin{tabular}{|c|c|c|c|c|}
\hline Jewler & 1 & ,2 & ,2 & 39,2 \\
\hline Judge & 1 & ,2 & ,2 & 39,4 \\
\hline Lawyer & 84 & 16,8 & 16,8 & 56,2 \\
\hline Librarian & 1 & ,2 & ,2 & 56,4 \\
\hline Manager & 16 & 3,2 & 3,2 & 59,6 \\
\hline Mechanic & 1 & ,2 & ,2 & 59,8 \\
\hline Nurse & 2 &, 4 &, 4 & 60,2 \\
\hline Officer & 1 & ,2 & ,2 & 60,4 \\
\hline Optition & 1 & ,2 & ,2 & 60,6 \\
\hline Pharmacist & 1 & ,2 & ,2 & 60,8 \\
\hline Police & 1 & ,2 & ,2 & 61,0 \\
\hline project manager & 1 & ,2 & ,2 & 61,2 \\
\hline publc employee & 6 & 1,2 & 1,2 & 62,4 \\
\hline public relation officer & 1 & ,2 & ,2 & 62,6 \\
\hline sales director & 3 & ,6 & ,6 & 63,2 \\
\hline sales person & 21 & 4,2 & 4,2 & 67,4 \\
\hline Secretary & 7 & 1,4 & 1,4 & 68,8 \\
\hline Selfemployed & 56 & 11,2 & 11,2 & 80,0 \\
\hline Student & 23 & 4,6 & 4,6 & 84,6 \\
\hline Teacher & 26 & 5,2 & 5,2 & 89,8 \\
\hline technician & 2 &, 4 &, 4 & 90,2 \\
\hline Waiter & 45 & 9,0 & 9,0 & 99,2 \\
\hline Worker & 2 &, 4 &, 4 & 99,6 \\
\hline Tailor & 2 & ,4 &, 4 & 100,0 \\
\hline Total & 500 & 100,0 & 100,0 & \\
\hline
\end{tabular}

Table 4: Job Distribution 


\section{Sector}

\begin{tabular}{|c|c|c|c|c|c|}
\hline & & Frequency & Percent & Valid Percent & Cumulative Percent \\
\hline \multirow[t]{32}{*}{ Valid } & accounting & 33 & 6,6 & 6,6 & 6,6 \\
\hline & advertisement & 8 & 1,6 & 1,6 & 8,2 \\
\hline & automotive & 6 & 1,2 & 1,2 & 9,4 \\
\hline & beauty and personal care & 2 &, 4 & ,4 & 9,8 \\
\hline & chemical & 2 &, 4 & ,4 & 10,2 \\
\hline & cleaning & 1 & ,2 & ,2 & 10,4 \\
\hline & communication & 1 & ,2 & ,2 & 10,6 \\
\hline & computers and software & 7 & 1,4 & 1,4 & 12,0 \\
\hline & construction & 19 & 3,8 & 3,8 & 15,8 \\
\hline & education & 44 & 8,8 & 8,8 & 24,6 \\
\hline & electronic & 1 & ,2 & ,2 & 24,8 \\
\hline & entertainment & 3 & ,6 & ,6 & 25,4 \\
\hline & fashion & 2 &, 4 &, 4 & 25,8 \\
\hline & finance & 32 & 6,4 & 6,4 & 32,2 \\
\hline & food and beverage industry & 11 & 2,2 & 2,2 & 34,4 \\
\hline & health & 21 & 4,2 & 4,2 & 38,6 \\
\hline & industry & 3 & ,6 & ,6 & 39,2 \\
\hline & information technology & 3 & ,6 & 6 & 39,8 \\
\hline & insurance & 7 & 1,4 & 1,4 & 41,2 \\
\hline & jewelry & 4 & ,8 & ,8 & 42,0 \\
\hline & leather & 1 & ,2 & ,2 & 42,2 \\
\hline & legal & 85 & 17,0 & 17,0 & 59,2 \\
\hline & library & 1 & ,2 & ,2 & 59,4 \\
\hline & media & 1 & ,2 & ,2 & 59,6 \\
\hline & other & 95 & 19,0 & 19,0 & 78,6 \\
\hline & public & 8 & 1,6 & 1,6 & 80,2 \\
\hline & retail & 27 & 5,4 & 5,4 & 85,6 \\
\hline & security & 6 & 1,2 & 1,2 & 86,8 \\
\hline & service & 30 & 6,0 & 6,0 & 92,8 \\
\hline & telecommunication & 2 & ,4 &, 4 & 93,2 \\
\hline & textile & 30 & 6,0 & 6,0 & 99,2 \\
\hline & tobacco & 1 & ,2 & ,2 & 99,4 \\
\hline
\end{tabular}

Vedat AKMAN Ph.D

$\mathrm{P}$ a g e | $6 \mid$ Emerging Markets Journal 


$\begin{array}{lllll}\text { tourism } & 3 & , 6 & , 6 & 100,0 \\ \text { Total } & 500 & 100,0 & 100,0 & \end{array}$

Table 5: Sector Distribution

\subsection{Factor Analysis}

Factor analysis is a technique used to identify the smallest number of decsribtive terms to explain the maximum amount of common variance in a correlation matrix. (Hill and Petty, 1995) Factors with Eigen values greater than 1.0 are retained.

\subsubsection{Factor Analysis for Ethical variables (FA\#1)}

Inspection of scree plot and Eigen values enabled the analysis to reduce the 21 business ethics variables into five factors.

\section{Factor 1: Work Environment Factor}

Factor one Work Environment Factor has 5 components included such as;

Q1. The rights which are provided to me in my workplace are enough and protective

Q2. I believe that I am working in an honest workplace

Q3. The social responsibility projects in my workplace are sufficient

Q4. I believe that my work environment is transparent

Q5. At workplace enough importance is given to business ethics

\section{Factor 2: Compelling Factor}

Q15. I find it unethical to use child labor (under 18) in my workplace

Q16. I find it unethical for workers at my workplace gossip about each other

Q17. I find it unethical for co-workers to blame each other for things they did not do

\section{Factor 3: Encouraging Factor}

Q12. In my workplace everybody works professionally

Q13. I am not faced with any lack of knowledge and miscompetence at my workplace

Q14. No discrimination or no preferential treatment at my workplace

\section{Factor 4: Family Factor}

Q20. An effective communication is very important at workplace

Q21. I believe the golden rule of having a good communication is to respect others

\section{Factor 5: Managerial Factor}

Q18. I will feel guilty if I see someone at work making a transaction at the expense of the company and not tell

Q11. Managers have an influence over the business ethics of the company

\subsubsection{Factor Analysis for Demographic Issues (FA\#2)}

Inspection of scree plot and Eigen values enabled the analysis to reduce the 4 variables into two main factors.

\section{Factor 1: Job and Sector Factor}

First factor includes both job and sector.

\section{Factor 2: Age and Gender Factor}

Second factor has two components age and gender.

These two factors will be used as the dependent variables and factor analysis \#1 factors will be taken as the independent variables in the following regression analysis. 


\section{Regression Analysis}

Analysis of Hypothesis 1 and Hypothesis 2 are seen in the table below.

\begin{tabular}{|c|c|c|c|}
\hline Dependent Variable & Independent Variable & Significance rate from ANOVA & Relationship \\
\hline Job and Sector (F1 of FA\#2) & $\begin{array}{l}\text { Factor 2: Compelling Factor } \\
\text { Child labor } \\
\text { Workplace gossip } \\
\text { Blame each-other }\end{array}$ & $\begin{array}{l}0,071 \\
0,321 \\
0,296 \\
0,264 \\
\end{array}$ & $\begin{array}{l}\text { Slight relationship } \\
\text { no relationship } \\
\text { no relationship } \\
\text { no relationship }\end{array}$ \\
\hline Job and Sector (F1 of FA\#2) & $\begin{array}{l}\text { Factor 3: Encouraging Factor (only } \\
\text { Q13) } \\
\text { (Q13):Facing lack of knowledge } \\
\text { and miscompetence at workplace }\end{array}$ & 0,052 & Strong relationship \\
\hline Job and Sector (F1 of FA\#2) & $\begin{array}{l}\text { Factor 5: Managerial Factor } \\
\text { Feeling guilty if I see someone } \\
\text { making a transaction at the expence } \\
\text { of the company and not tell } \\
\text { Managers have an influence over } \\
\text { the business ethics of the company }\end{array}$ & $\begin{array}{l}0,017 \\
0,013 \\
0,077 \\
\end{array}$ & $\begin{array}{l}\text { Strong relationship } \\
\text { Strong relationship } \\
\text { Slight relationship }\end{array}$ \\
\hline Age and Gender (F2of FA\#2) & Job and Sector & 0,000 & Strong relationship \\
\hline Age and Gender (F2of FA\#2) & $\begin{array}{l}\text { Factor 2: Compelling Factor } \\
\text { Child labor } \\
\text { Workplace gossip } \\
\text { Blame each-other }\end{array}$ & 0,071 & Slight relationship \\
\hline Age and Gender (F2of FA\#2) & $\begin{array}{l}\text { Factor 4: Family Factor } \\
\text { Effective communication is very } \\
\text { important } \\
\text { Having good relationship is to } \\
\text { respect others }\end{array}$ & $\begin{array}{l}0,076 \\
0,065 \\
0,065 \\
\end{array}$ & $\begin{array}{l}\text { Slight relationship } \\
\text { Slight relationship } \\
\text { Slight relationship }\end{array}$ \\
\hline Age and Gender (F2of FA\#2) & $\begin{array}{l}\text { Factor 5: Managerial Factor } \\
\text { Feeling guilty if I see someone } \\
\text { making a transaction at the expence } \\
\text { of the company and not tell } \\
\text { Managers have an influence over } \\
\text { the business ethics of the company }\end{array}$ & $\begin{array}{l}0,021 \\
0,095 \\
0,052\end{array}$ & $\begin{array}{l}\text { Strong relationship } \\
\text { No relationship } \\
\text { Strong relationship }\end{array}$ \\
\hline
\end{tabular}

Table 6: ANOVA Analysis Results

The ANOVA done for this analysis shows that if the significant value is greater than 0.05 which means that the independent variables (business ethics variables) do not explain the total variation very well according to the dependent variable (age and gender/ job and sectorthe null hypothesis is rejected, meaning that there is no relationship between age, gender and business ethics variables / job and sector and business ethichs variables.
The ANOVA done for this analysis shows that if the significant value is smaller than 0.05 which means that the independent variables (business ethics variables) does explain the total variation very well according to the dependent variable (age and gender/job and sector). So we accept the null hypothesis, meaning that there is a relationship between age, gender and business ethics/ job and sector and business ethichs variables.

The ANOVA done for this analysis shows that if the significant value is slightly above 0,05 
which means that the independent variables (business ethics variables) does explain the total variation slightly but not bad according to the dependent variable (age and gender/job and sector). So we accept the null hypothesis, meaning that there is a slight relationship between age, gender and business ethics/ job and sector and business ethichs variables.

\section{Conclusion}

This study explored the influence of gender, age, job profession and sector choices towards factors affecting business ethics in Turkey. Self-administered questionnaire with scale of 1-5 was used to measure attitudes towards business ethics. The reliability test resulted with a cronbach alpha of 0,692 shows that the data is consistantly reliable to analyse especially for factor analysis and regression analysis.

Regarding the frequency distribution of the data $30.8 \%$ of the respondents were at the age of 18 through $25,25.6 \%$ through 26 to 30 and $15.4 \%$ through 31 to 35 . Cumulative 3 percentage of age shows that almost $72 \%$ of the respndents were at the age through 18 to $35.49 \%$ of the respondents were female and the rest were male. $73.8 \%$ of the respondents were university graduates and $21 \%$ were highscholl graduates. The job distribution of respondents was huge. The job distribution was among 55 different job titles. The repsondents had a sector distribution of 33 which is listed in Table 5 above.

Factor analysis was done twice for different reasons. The first factor analysis (FA\#1) was tested for the 21 questions included in the questionnaire related to business ethics variables. The second factor analysis (FA\#2) was done to gain the important factors for the demographic issues.

Each variable from factor analysis were retained for the regression analysis.

According to the results of regression analysis job and sector factor has a strong relationship with the encouraging factor specifically with 'facing lack of knowledge and miscompetence at workplace'; with managerial factor in addition specifically with 'feeling guilty if the worker sees someone making a transaction at the expence of the company and not tell' variable. Job and sector has a slight relationship with the compelling factor but no relationship with its components. It also has slight relationship with one of the components of managerial factor which is 'managers have an influence over the business ethics of the company'. Age and gender factor has a strong relationship with managerial factor same as it had with job and sector fctor. Age and gender factor has a slight relationship with the compelling factor but no relationship with its components; with family factor and its components such as 'effective coomunication being very important' and 'having good relationship to show respect to people.

Recent findings in the literature pointed us to the fact that, open to conflict, most previous research in the field were dominated by normative approach. (Hosmer, 2000) There is a lack of empirical research which this paper hopes to fill by generating facts through empirical research to provide solutions to some of the conflicts. Hopefully, our findings could be incorporated into acceptable further normative studies and we would reach our goal. 


\section{Discussion}

So our current findings with five components under factor one and their relationship to factor two with two components (job,sector, and gender, age \& education) which is trying to establish positive correlation among them. In our case they are job, sector and gender and age, education is not. Our result confirms with the Turkish tradition that family is the key factor replacing education in ethics. When we take into consideration the current availability of ethics education over PA's and their affectiveness in Turkey, our result is not suprising.

Our current findings where job, sector and gender and age are positively correlated with perception of business ethics and no significant correlation found between education. Are coherant with the previous works. Number of directions for the future research might be suggessted forexample more detailed view of dominant professions in terms of perception of business ethics might be in order. 


\section{References}

1. Joan Marie McMahon, "An Analysis of the Factor Structure of the Multidimensional Ethics Scale and a Perceived Moral Intensity Scale, and the Effects of Moral Intensity on Ethical Judgment", Dissertation submitted to the Faculty of the Virginia Polytechnic Institute and State University, 2002, pp.1-188.

2. Hortacsu, Ayfer and Ozkan Gunay, E. Nur, "Ethical Issues and Attitude in the Turkish Banking Sector", June 2004, MPRA Paper, No. 26338, posted 31. October 2010. (http://mpra.ub.uni-muenchen.de/26338/)

3. Gülçimen Yurtsever, "The Ethical Beliefs of Turkish Consumers”, D.E.Ü.İ.İ.B.F.Dergisi Issuet:13, No:II, 1998, pp:135-146.

4. “Dünyada ve Türkiye'de İş Etiği Yönetimi”Publicatin No: TÜSİAD/T-2009-06-492, June 2009, pp.1-151.

5. Gregory C. Petty, "Work Ethic Characteristics: Perceived Work Ethics of Supervisors and Workers", Journal of Industrial Teacher Education, Volume 42, Number 2, 2005, pp.1-20.

6. Ethics for the Prevention of Corruption in Turkey (TYEC), Council of Europe and Council of Ethics for the Public Services in Turkey: Academic Researches on Public Ethics, Vol. I-II, Nov. 2009.

7. Choe Kum-Lung, "Attitude Towards Business Ethics: Examining the Influence of Religiosity, Gender and EDucation Levels”, International Journa of Marketing Studies, Vol.2, No.1, May 2010, pp. 225-232

8. Chris Perryer and Catherine Jordan, "The Influence of Gender, Age, Culture and other Factors on Ethical Beliefs: A Comparative Study in Australia and Singapore", Public Administration and Management: An Interactive Journal, 7, 4, 2002, pp. 367-382.

9. Zohreh Tahmasebi, Ahmad Dibavar and Nasrin Pirsemsari, "Factors Affecting Ethical Behavior of Employees", AIMS International Conference on Value-Based Management, August 11-13, 2010.

10. M.G. Serap (Atakan) Ekin and S. Hande Tezölmez, "Business Ethics in Turkey: An Empirical Investigation with Special Emphasis on Gender", Journal of Business Ethics 18,1999, pp. 17-34

11. İGİAD, "İş Ahlakı Raporu”, İstanbul, İGİAD Yayınları, No.9, Rapor.2, 2008. 